\title{
The Appeal of the Primal Leader: Human Evolution and Donald J. Trump
}

\author{
Dan P. McAdams
}

\begin{abstract}
Drawing on the distinction between dominance and prestige as two evolutionarily grounded strategies for attaining status in human groups, this essay examines an underappreciated feature of Donald Trump's appeal to the millions of American voters who elected him president in 2016 — his uncanny ability to channel primal dominance. Like the alpha male of a chimpanzee colony, Trump leads (and inspires) through intimidation, bluster, and threat, and through the establishment of short-term, opportunistic relationships with other high-status agents. Whereas domain-specific expertise confers status in the prestige paradigm, dominant leaders derogate expertise in order to establish a direct, authoritarian connection to their constituency. Trump's leadership style derives readily from his personality makeup, which entails a combustible temperament mixture of high extraversion and low agreeableness, a motivational agenda centered on extreme narcissism, and an internalized life story that tracks the exploits of an intrepid warrior who must forever fight to win in a Hobbesian world of carnage.
\end{abstract}

Keywords: Donald J. Trump, dominance psychology, prestige psychology, leadership, authoritarianism, personality, chimpanzees

Nearly 63 million Americans voted for Donald J. Trump in the 2016 United States presidential election. His victory defied expert opinion and shocked the world. How could a man widely dismissed as a carnival barker and a narcissist, with no political or military experience whatsoever, capture the most powerful political office on the planet? How could a candidate who performed so poorly in the presidential debates, who routinely uttered wild falsehoods and bizarre rants, who mocked disabled people and war heroes, refused to release his tax forms, boasted about groping women, dismissed climate change as a Chinese hoax, labeled Mexican immigrants as rapists, courted white supremacists, and insulted countless members of his own political party-how could somebody like that possibly garner the trust and the support of the American people?
In the aftermath of the electoral earthquake, pollsters and social scientists have put forth a wide range of plausible explanations. Many point to procedural issues, such as the vagaries of the electoral college (after all, Hillary Clinton received 2.8 million more votes in the popular count) and the last-minute resumption of an FBI investigation into Mrs. Clinton's e-mail history (which turned up nothing). Other explanations underscore substantive issues, such as Trump's success in channeling the angst of white working-class voters (e.g., Williams 2016), the rejection of globalism among many citizens of democracies today (e.g., Haidt 2016), Trump's pro-business agenda and promise to reduce government regulations, his pledge to appoint conservative judges, and the possibility that widespread sexism in American society worked against the election of the first female president in U.S. history. 
With respect to the prospect of sexism, it is especially puzzling to note that $53 \%$ of white women voted for Donald Trump. In an effort to understand why so many women would reject one of their own, a New York Times reporter asked a range of women to explain in detail their reasons for supporting Mr. Trump (Chira 2017). Although the respondents did point to certain recognizable issues (e.g., Second Amendment rights, Mr. Trump's business acumen), the stories they told were, on the whole, astonishingly incoherent and self-contradictory. A self-identified feminist said she liked Trump's tough stance on immigration, and to prove her point described an unpleasant exchange she had with a Somali taxi driver who "lectured me for 35 minutes" about "how women in America have too much freedom." In other words, she voted against the one feminist running for president, and in favor of a man widely decried as a sexist, because tough restrictions on immigration may help rid the country of sexist men. A 48-yearold mortgage broker "was leaning toward [the liberal] Bernie Sanders" at first, but she voted for Trump in the general election because "he reminds me of my ex-husband." A preschool teacher supported Obama in 2012 and planned to vote for Clinton until her 8-yearold son convinced her to attend a Trump rally. She reported that Trump's presence at the rally was "calming," and she added that Hillary Clinton has not been a consistent supporter of women's abortion rights. Yet on the campaign trail, Mr. Trump raised the prospect of criminalizing abortion.

These responses, among many others, reinforce an assertion that certain political scientists and psychologists have made for decades: people don't fully (and consciously) understand why they vote the way they do. Whereas many voters believe that they carefully weigh the policy issues and the relative merits of candidates, reason often takes a back seat to emotion, instinct, and impulse-perhaps especially when considering a political figure as polarizing as Donald
Trump. Despite seemingly insurmountable odds and personal shortcomings that would have sunk nearly any other candidate, Trump prevailed in the 2016 election, I believe, because of a primal appeal that has generally gone unspoken. It is an appeal that derives ultimately from our human evolutionary heritage, updated for the current moment by the recent rise of authoritarianism in Western democracies and the emergence of a singular personality that is both remarkably strange and deeply familiar.

\section{THE PSYCHOLOGY OF PRESTIGE}

In the early 1980s, Donald Trump achieved a series of major successes in the Manhattan real estate market, culminating in the construction of Trump Tower on the corner of Fifty-Seventh Street and Fifth Avenue. Trump's early accomplishments, his growing wealth, and his flamboyant lifestyle attracted considerable media attention at the time, making him a local celebrity in New York. His fame increased dramatically, however, with the publication of The Art of the Deal in 1987, ghost-written by the journalist Tony Schwartz. The best-selling book described formative events in Trump's life and outlined the principles he followed to achieve success in business. "Deals are my art form," Trump $(1987,1)$ wrote. "Other people paint beautifully on canvas or write wonderful poetry. I like making deals, preferably big deals. That's how I get my kicks."

In The Art of the Deal, Donald Trump burst onto the world stage as an expert, a man who achieved prestige in society by virtue of a particular skill or expertise. As such, Trump seemed to embrace a strategy for attaining status in human groups that may be a million years old. The evolutionary biologist and anthropologist Joseph Henrich (2016) has argued that the value of prestige derives from the critical role of culture in human evolution:

The key to understanding how humans evolved and why we are so different from other animals is to recognize that we are a cultural species. 
Probably over a million years ago, members of our evolutionary lineage began learning from each other in such a way that culture became cumulative. That is, hunting practices, tool-making skills, tracking knowledge, and edible plant knowledge began to improve and aggregate-by learning from others — so that one generation could build on and hone the skills and know-how gleaned from the previous generations. (Henrich 2016, 3)

For a cultural species like ours, each generation builds on the advances of previous generations. Cumulative cultural knowledge-be it instrumental (technological, economic) or expressive (artistic, moral) — is transmitted over time by individuals who acquire culturally valued expertise. These experts garner prestige within a human group to the extent that other individuals (let us call them "learners") seek to attain the knowledge that the experts possess, or seek to emulate them by virtue of their expertise. Natural selection should favor cultural learners who can figure out who the best experts are and can design effective ways of obtaining the valuable knowledge those experts possess, as through ingratiating themselves to the experts, imitating them, seeking to be in close proximity to them, or developing long-term relationships with experts to promote cultural learning (Henrich and Gil-White 2001). Through culture-gene coevolution, then, human nature has gradually domesticated itself over the past million years or so, Henrich (2016) argues, to the point where human beings deeply value group norms grounded in cultural knowledge and benefit from intensive enculturation practices wherein learners emulate prestigious experts.

Within hunting and gathering bands of Homo sapiens, prestige was (and is) the main ticket to social status. Anthropologists generally believe that human hunters and foragers have typically formed relatively egalitarian communities that manage to distribute power across a range of cultural experts (Boehm 1999). Of course, no human group is ever devoid of hierarchy, but the mobile human bands that prevailed on the planet 100,000 years ago, and probably much earlier, developed cultural practices and social norms that mitigated the influence of potential despots. In the words of Boehm (1999, 4), early humans "lived in what might be called societies of equals, with minimal political centralization and no social classes. Everyone participated in group decisions, and outside the family there were no dominators." In these "moral communities" (8), social rank was mainly (though not exclusively) a function of prestige, which itself stemmed from expertise in specific cultural domains, such as hunting, healing, cooking, caregiving, and the arts of defense.

Consistent with our evolutionary lineage, then, the human mind is well prepared to appreciate the intricacies of a prestige psychology. Within such a framework, honor and social standing are naturally accorded to individuals for their information quality - that is, in recognition of the culturally valued skills, talents, and knowledge they possess and to which learners assiduously seek access. Prestigious people are freely admired and emulated; they do not need to coerce others to obtain support. Prestigious people are often expected to rise to positions of leadership within groups. As leaders, moreover, they are expected to call upon the advice of other experts, to encourage collaboration among subordinates in order to solve group problems, to respect group norms and work within established institutions, and to demonstrate some degree of magnanimity, generosity, forbearance, and dignity in their leadership roles (Maner and Case 2016). They are expected to commit themselves to the welfare of the group, rather than to self-aggrandizement. Observing hunter-gatherers on the remote Andaman Islands more than 100 years ago, the renowned British anthropologist A. R. Radcliffe Brown wrote:

Besides the respect for seniority, there is another important factor in the regulation of social life, namely the respect for certain 
personal qualities. These qualities are skill in hunting and warfare, generosity and kindness, and freedom from bad temper. A man possessing them inevitably acquires a position of influence in the community. His opinion on any subject carries more weight than that of another. (from Henrich 2016, 118).

Social psychologists have conducted empirical studies of business teams in order to flesh out the psychology of prestige (Cheng et al. 2013; Maner and Case 2016). They find that when leadership is framed in prestige terms, rather than in terms of sheer dominance or coercion, team members enjoy their interactions more and develop more creative solutions to problems. Prestige-oriented leaders tend to be especially encouraging of other talented group members, viewing them as allies rather than rivals, tend to share information freely with other group members, and tend to match subordinates to the appropriate tasks wherein their respective skill sets can be best utilized.

If one knew nothing else about Donald Trump beyond the fact that he once published a book sharing culturally valued expertise in the real estate industry, one might expect that his own approach to leadership would follow the paradigm of prestige. But, of course, nothing could be further from the truth, as even Trump's most ardent admirers would acknowledge. Even a casual reading of The Art of the Deal reveals that the cultural knowledge Donald Trump aims to transmit is not so much a specialized portfolio formulated to address a specific problem in culture but rather a more general set of strategies aimed at achieving social dominance-dominance in virtually any context in which "deals" are to be made, from real estate to politics to interpersonal relationships. "Think big," he counsels (Trump 1987, 47). "Fight back" (58). "Use your leverage" (53). "The best thing you can do is deal from strength" (53). And "sometimes, part of making a deal is denigrating your competition” (108).

Donald Trump completely disavows the psychology of prestige. He renounces this feature of human nature as strongly as he renounces anything. In its place, Trump harkens back to an evolutionarily older paradigm for achieving status in primate groups. It is the paradigm of brute dominance, an atavistic proclivity whose primal appeal never seems to fade.

\section{CHIMPANZEE POLITICS}

From early 1974 through the bulk of 1976, a male chimpanzee named Yeroen held the position of alpha leader in the large, open-air chimpanzee colony at Burgers Zoo in Arnhem, the Netherlands (de Waal 2007). His reign was roughly coterminous with the administration of President Gerald R. Ford in the United States. Yeroen achieved his exalted status not through prestige, however, but through repeated displays of social dominance, like this one:

A heavy steam engine, an advancing tank, an attacking rhinoceros; all are images of contained power ready to ride roughshod over everything in its path. So it was with Yeroen during a charging display. In his heyday he would charge straight at a dozen apes, his hair on end, and scatter them in all directions. None of the apes dared to remain seated when Yeroen approached, stamping his feet rhythmically. Long before he reached them they would be up, the mothers with their children on their backs or under their bellies, ready to make a quick getaway. Then the air would be filled with the sound of screaming and barking as the apes fled in panic. Sometimes this would be accompanied by blows. Then, as suddenly as the din had begun, peace would return. Yeroen would seat himself, and the other apes would hasten to pay their respects to him. Like a king he accepted this mass homage as his due. (de Waal 2007, 77).

Both in the wild and in captivity, adult male chimpanzees organize themselves into strict hierarchies. The top chimp achieves his standing through aggression, intimidation, and threat. Prerequisites for the top post often include 
being large and being strong, though smaller dominant chimps can compensate through powerful vocal displays and other intimidating tactics. Alpha chimps regularly exhibit piloerection-their hair stands on end, as with Yeroen in the charging display-which makes them appear even larger than they really are. In addition, they must be endowed with the kinds of temperament traits that drive social dominance (introversion and fearfulness are disqualifiers). And they must be amenable to forging coalitions with other high-status chimps in the group, lest their subordinates plot to overthrow them. In Chimpanzee Politics, Frans de Waal (2007) famously described these coalitions as short-term Machiavellian projects of surprising intricacy. Utterly pragmatic, rival chimps may severely injure each other in a battle for dominance, and then engage in mutual grooming and other friendly behaviors to consolidate rank order once the battle is over. When (after a 72-day uprising) Luit finally overthrew Yeroen to achieve top status in 1976, Yeroen angled to become his closest ally.

The human and chimpanzee lineages split off from their common ancestor 5 to 7 million years ago. What both lines took with them was an abiding proclivity for social hierarchy and a corresponding psychology of dominance. Therefore, the human expectation that social status can be seized through brute force and intimidation, that the strongest and the biggest and boldest will lord it over the rank and file, is very old, awesomely intuitive, and deeply ingrained. Its younger rival—prestige-was never able to dislodge dominance from the human mind, even during the long and relatively egalitarian epoch when hunter-gatherer bands and tribes crisscrossed the African continent. Indeed, dominance got its second wind, as it were, with the advent of agriculture, around 12,000 years ago, and the rise of kingdoms, city-states, and nations (Boehm 1999). Ancient kingdoms were brutally hierarchical, with monarchs at the top and slaves at the bottom. Flashing forward to the twenty-first century, dominance and prestige compete with each other as two evolutionarily grounded strategies for attaining status in human groups, contoured by wide variations across the globe in government structures, political ideologies, religions, economies, and wealth.

When the first edition of Chimpanzee Politics appeared in 1982, readers were struck by how much chimps turn out to be like humans. But the case of Donald Trump shows how much humans turn out to be like chimps.

Trump is physically big, and dynamic. He gives the impression of a volcano about to explode. When I watched the Republican debates, I could not keep my eyes off of him, even when others were speaking. He is more overtly aggressive than any political figure in the United States today, so aggressive, so insulting, so egregiously self-promoting that you think he might be bluffing-but is he? What if he isn't? Bluffing, it should be noted, is a cardinal strategy in the alpha chimp repertoire. It is also prevalent in those agonistic life contexts Donald Trump knows so well-the Manhattan real estate market, for example, the world of professional wrestling, and the cutthroat ethos of his reality show, The Apprentice. On Twitter, Trump's incendiary tweets are like Yeroen's charging displays, designed to intimidate. Former communications director for President George W. Bush, Nicole Wallace has labeled Trump a "cyberbully," and Robert Dallek, a presidential historian, described as "unprecedented" and "beneath the dignity of the office" Trump's verbal attacks on everyday citizens who disagree with him (Shear 2016). Teddy Roosevelt believed that the leader of a great nation, and the nation itself, should "speak softly, but carry a big stick." Trump yells loudly; indeed, he hoots, screams, and screeches-mainly to vent his anger and to invoke fear. And now that he is president, he also carries the big stick.

The role of fear is central to a dominance psychology (Cheng et al. 2013; Henrich and Gil-White 2001). The alpha male cannot sustain 
the dominant position unless others in the group fear him. Accordingly, elected officials may go along with certain proposals they would typically oppose out of fear of offending Trump's political base. Business leaders may fear retaliation from Trump, in the form of steep import taxes, if they decide to move their operations out of the country.

For a U.S. president beholden to the principles of dominance, fear may also prove useful in international relations. A prominent military expert has written that it is a good thing for foreign leaders to fear the president of the United States (Moyar 2016). It is good in the case of the nation's enemies, in that they may think twice about challenging U.S. power, and it is good in the case of the nation's allies, who "must know that the world's most powerful nation is prepared to practice tough love if they take actions inconsistent with the strength of the United States or the stability of the international system." Trump is more than eager to provoke fear-at home and abroad. "Sometime you have to be a little wild" (Trump 1987, 5). The sentiment channels what Richard M. Nixon once termed the "madman theory" of leadership (Moyar 2016). The president should be a little unpredictable and reckless, Nixon believed, to convince America's enemies, and maybe even its friends, that he might just do something really crazy—so watch out!

So the dominance-oriented leader relies on fear and intimidation to remain on top, but he is also eager to create short-term coalitions to accomplish leadership goals. Trump has always been a pragmatic dealmaker, willing to form expedient working relationships with former opponents and enemies, which resemble the short-term, opportunistic collaborations described by de Waal (2007). "I don't hold it against people that they opposed me" (Trump 1987 , 6). Former targets of his wrath have become business associates and members of his Cabinet. On the one hand, Trump has shown he can forgive and forget in order to promote his agenda. On the other, he will quickly fire an associate, or terminate a friendship, when the relationship no longer serves his immediate interests (D'Antonio 2015).

Early in the Trump administration, this kind of contractual, short-term approach to dealmaking has manifested itself most notably in international relations - an arena wherein diplomats aim to build trust and loyalty among allies and long-term bonds of commitment between nation-states. Trump's first meetings or phone calls with the heads of state of Mexico, Australia, the UK, and Germany were fraught with awkwardness and high levels of conflict, even though these four nations have been good friends of the United States for more than half a century. After President Trump accused America's closest ally-the UK-of colluding with former President Obama to wiretap Trump Tower, the diplomatic community was aghast. Jeremy Shapiro, a former State Department official who is research director at the European Council on Foreign Relations in London, remarked that it is very easy in the beginning to have a good and pleasant meeting with President Trump. But he cannot be trusted in the long run, for he seems to move from the exigencies of one contractual moment to the next, focused unswervingly on what will work in the immediate situation rather than on long-term consequences. If you make an agreement on Monday, he may no longer seem to recall it on Wednesday, if indeed Wednesday raises new contingencies. "He'll promise you the world," Shapiro said (Baker and Erlanger 2017). "And 48 hours later, he'll betray you without a thought. He won't even know that he'll be betraying you."

Social-psychological research shows that dominance gets mixed reviews in the context of group leadership, though it remains a stubbornly viable strategy (Maner and Case 2016). Whereas people enjoy working under prestige-oriented leaders more than dominance-oriented leaders, groups tend to achieve solutions more quickly under conditions of dominance. When dominance-oriented 
leaders feel that their authority is threatened, they may withhold information from group members, monitor their actions closely, discourage collaborations, and actively undermine the development of talented subordinates - all with the aim of retaining their own powerful status (Maner and Case 2016). Rather than praise group members, dominant leaders may take all the credit for the group's success, basking in what Tracy and Robins (2007) call hubristic pride. Tracy and Robins consider hubristic pride to be the human analogue of the ostentatious bluff displays that dominant chimps express.

The concept of hubristic pride also points to one of the most telling distinctions between how dominant and prestigious leaders think about themselves and the groups they lead. It is good when human beings feel pride for their accomplishments. Many expressions of authentic pride signal the success that comes from hard work, careful study, long-term commitment, and the creative or judicious application of human ingenuity. By contrast, the preening expression of hubristic pride typically celebrates the self-the pride I may feel for simply being the great (brilliant, powerful) person that I happen to be. Authentic pride celebrates what I have done, whereas hubristic pride celebrates who I am. The distinction tracks the dichotomy articulated by the social psychologist Carol Dweck (Molden and Dweck 2006) between essentialist and growth mind-sets. An essentialist mind-set suggests that people have essential and unchanging characteristics-I am smart or I am dumb, for example, and my standing on that dimension (let us call it intelligence) is not going to change. By contrast, a growth mind-set suggests that people's characteristics can change, grow, and improve (or decline) as a function of experience: I flunked that test, but if I study harder next time, I will do better; I used to be a terrible golfer, but I have improved with practice.

For as long as he has been in the public eye, Donald Trump has boasted about his general intelligence. On the campaign trail, Trump repeatedly claimed that he was smarter than all of the generals in the military and, therefore, did not need their counsel. As president-elect, he claimed that he would not need to receive daily intelligence briefings once in office because he was smart enough to figure out what needed to be done on his own. He has also projected the general trait of intelligence onto others when it reflects well on him. For example, the day before he was inaugurated, Trump announced, "We have by far the highest IQ of any Cabinet ever assembled" (Shear 2017). He has tweeted admiration for Vladimir Putin's intelligence: "Great move . . . (by V. Putin)-I always knew he was very smart!" Trump attributes his own intelligence to a "gift" from his father. In a weirdly sentimental passage from his campaign manifesto, Crippled America, Trump (2015) thanks his father for the gift: "When my father passed away at the age of 93, he left his estate to his children. . . What he left me, much more importantly, were the best "genes" that anybody could get. He was a special man and father" (99).

Trump's repeated invocation of the broad trait of intelligence reveals an essentialist mindset that, in its deep logic, celebrates dominance and impugns prestige. Trump views intelligence as a fixed entity in a person, an essence that is impervious to change. It comes from your genes, Trump asserts, as he thanks his father for the wonderful genetic gift. Intelligence is broad and multipurpose. And so is dominance. If you are smart, you can figure out anything, and you don't need experts to help you out. If you are supremely dominant, like Yeroen, others' expertise is moot.

Whether we are talking about chimpanzees or human beings, the dominant leader possesses a general, all-purpose asset-that is, dominance. He is the "killer" and the "king"two of his father's favorite appellations for the young Donald, who was thrilled to be described as such (D'Antonio 2015). The psychology of prestige, by contrast, rejects the idea that any single individual can do (or know) it all. 
Culture builds from one generation to the next, and the critical knowledge that pushes culture forward resides in the minds of many different experts, who garner prestige because of their expertise. Whereas dominance, then, is akin to a general essence (parallel to Trump's lay conception of intelligence), expertise is domain-specific (instantiated within particular fields or domains, such as economics, chess, cooking, and poetry), something learned within a given tradition of inquiry and skill. In the prestige model, leadership itself is a kind of expertise, and good leaders call upon the expertise of others. From the standpoint of a prestige psychology, we do not expect the president of the United States to know more about military strategy than his generals, any more than we would expect him to be a better physicist than Stephen Hawking, or a better novelist than Toni Morrison.

A man who does not read books and shows little curiosity regarding human achievements in the arts, humanities, and sciences, Donald Trump has limited appreciation for experts of any kind, typically writing them off as elitists. Although he has pledged to create millions of high-paying jobs for Americans, Trump has effectively rejected any advice from mainstream economists, even those who have traditionally lined up with conservative presidents. In derogating experts and ignoring the prestige that they have traditionally achieved, Trump has effectively channeled a rising populist suspicion of intellectuals and other elite professionals. This dominance strategy has won him many supporters among poorly educated white Americans. Not surprisingly, it has become a source of alarm among experts themselves. Less than a week after Donald Trump was sworn in as president, the Bulletin of Atomic Scientists moved its famous Doomsday Clock forward by 30 seconds (2.5 minutes before midnight), to indicate how close the scientists involved feel the earth is to an imminent disaster. The clock has not been this close to midnight since 1953, the year the United States and the Soviet Union conducted competing tests of the hydrogen bomb. In explaining the rationale for the move, the executive director, Rachel Bronson, said: "We're so concerned about the rhetoric [of Donald Trump], and the lack of respect for expertise" (Bromwich 2017).

\section{THE AUTHORITARIAN DYNAMIC}

Since he was a young man, a consistently Hobbesian sensibility has run through Donald Trump's discourse about the nature of humankind and the experience of living in America. Consider three texts, spread across 35 years:

Man is the most vicious of all animals, and life is a series of battles ending in victory or defeat. (from a 1981 People magazine interview)

New York. My city. Where the wheels of the global economy never stop turning. A concrete metropolis of unparalleled strength and purpose that drives the business world. Manhattan is a tough place. This island is the real jungle. If you're not careful, it can chew you up and spit you out. But if you work hard, you can really hit it big, and I mean really big. (opening segment for episodes of the reality TV show The Apprentice, beginning in 2004)

Mothers and children trapped in poverty in our inner cities, rusted-out factories scattered like tombstones across the landscape of our nation. An education system flush with cash but which leaves our young and beautiful students deprived of all knowledge. And the crime and the gangs that have stolen too many lives and robbed our country of so much unrealized potential. The American carnage stops here and stops right now. (President Trump's inaugural address, delivered on January 20, 2017)

The philosophical constant in Donald Trump's life, going back even to childhood, is his conviction that the world is a dangerous place 
(McAdams 2016). It does not matter that he grew up in a wealthy and secure family. It does not matter that the crime rate is near historic lows in the United States today, or that the economy has recovered fairly well from the 2008 recession. Without a doubt, the United States faces tremendous challenges at this moment in history, and the loss of high-paying working-class jobs is certainly near the top of the list. Nonetheless, it is hard to imagine that any other candidate who ran for the presidency in 2016, Democrat or Republican, would deliver an inaugural address that characterized the current state of the nation as one of "carnage."

There are at last three political responses to a Hobbesian worldview. The first is classic conservatism, which emphasizes prudence and caution in a dangerous world, looks to the wisdom of the past and traditional institutions for guidance and support, and asks little of government except to assure the safety of the governed (Allitt 2009; Sullivan 2006). Think: Ronald Reagan. The second is fundamentalism, which grounds a sense of security and certitude in strict adherence to explicit dogmas, originalist interpretations of canonical texts, and the like (Sullivan 2006). Think: Ted Cruz, or the late Supreme Court justice, Antonin Scalia. The third is authoritarianism. Think: okay, it is obvious.

With authoritarianism, a dominant authority - typically personified in a single leaderprotects the people from danger, takes care of their needs, and consolidates their identification with the group. In order to do so, the dominant leader must make clear distinctions between the "good" people who are members of the in-group (e.g., patriotic citizens who possess the essences that render them legitimate, be those essences the right ethnicity, ideology, religion, or some other identifying orientation) and the "bad" people, who are relegated to the out-group, be those "bad" people insiders who do not have the right essences (deviants, apostates, etc.) or threatening outsiders. In extreme cases, author- itarianism can result in dehumanization of outgroup members - the enemy (or the deviant) is viewed to be less than human, and thereby not subject to the rights and protections typically accorded to human beings (Haslam and Stratemeyer 2016). When he announced his candidacy in 2015, Trump's opening salvo demonized illegal Mexican immigrants as "rapists" and "drug dealers." He went on to reframe the multivalent threats that Americans face today as a simple Manichean battle against "radical Islamic terrorism." To protect the good in-group members from their dehumanized enemies, he promised to build a wall on the Mexican border (and force Mexicans to pay for it) and to deny Muslims (for at least a short term) entry into the United States. Research in social psychology has shown that when human beings are stimulated to think about conflict with out-groups, they tend to increase their preference for highly dominant, authoritarian leaders (Lausten and Petersen 2017).

It is important to note that authoritarianism lies not so much in the leader himself as in the dynamic space between the leader and his followers. Indeed, social scientists developed the concept of the authoritarian personality during World War II to explain why the citizens of fascist states supported leaders like Hitler and Mussolini (Adorno et al. 1950). As measured by researchers today, right-wing authoritarianism (RWA) assesses attitudes and values revolving around strict adherence to society's traditional norms, submission to strong authorities who personify or reinforce those norms, and antipathy — to the point of hatred and aggressiontoward those who either challenge norms or lie outside their orbit (Altemeyer 1996). Among white Americans, high scores on RWA tend to be associated with prejudice against a wide range of out-groups, including gays and lesbians, African Americans, Muslims, and immigrants. Seen in a more benign light, however, authoritarian value systems also tend to reinforce the importance of a coherent moral order, to be found in more traditional, homogeneous 
communities (Haidt 2016). In the dialectic of globalism versus nationalism, citizens with authoritarian values are strongly on the side of nationalism. The political scientists Marc Hetherington and Jonathan Weiler (2011) have analyzed data on political trends to suggest that authoritarianism has become a more powerful force in American politics over the past decade. The popular appeal of the authoritarian dynamic may also be observed in the recent rise of Far Right nationalist parties in Europe. In a poll of registered voters conducted in December 2015, Matthew MacWilliams (2016) found that a high score on a questionnaire measure of authoritarianism was the single strongest predictor of expressing political support for Donald Trump.

Donald Trump's inimitable personality profile appears tailor-made for assuming the dominant role in the authoritarian dynamic (McAdams 2015, 2016). At the level of basic temperament traits, Trump has always displayed high levels of extraversion (social dominance, gregariousness, reward-seeking) and remarkably low levels of agreeableness (humility, altruism, care, empathy). Prognosticating from research findings regarding these two cardinal human traits, Trump should prove to be a bold and impulsive chief executive who is willing to take game-changing risks with little concern for the collateral damage that may result. Low levels of agreeableness are also associated with telling lies, among both normal people and presidents (Rubenzer and Faschingbauer 2004). Research also shows that the combination of high extraversion and low agreeableness is correlated with a particular cluster of values and beliefs that comprise what social psychologists call social dominance orientation (SDO; Duckitt and Sibley 2010). Individuals with high scores on SDO tend to believe that their own group (e.g., race, ethnicity, nation, religion) is innately superior to all other groups and will, therefore, prevail in the end. The high-energy extraversion and extreme disagreeableness are, in Trump's particular case, both fueled by anger- the anger that ignites his aggressive outbursts but also stokes his desire to win the adoration of others. Combined with a considerable gift for humor (which may also be aggressive), anger lies at the thumping heart of Trump's authoritarian charisma.

If angry extraversion and disagreeableness characterize his temperament style, narcissism captures Trump's underlying motivational agenda. Although some dominant leaders ascribe to an overarching set of values and goals, Trump has no political philosophy to speak of, and his central goal in life is, and always has been, to promote himself. In Trump's case, narcissism seems to play well with the authoritarian dynamic. People who look for salvation and safety in a dominant leader may feel that their choice is especially well justified when that dominant leader himself truly believes that he is a savior, believes that his supreme essence-his superior intelligence, his charismatic dominance, his single-minded devotion to a grandiose self-will triumph in the end. Speaking for Christian evangelicals, Jerry Falwell, Jr., explained his early support for Trump in the Republican primaries this way: "All the social issuestraditional family values, abortion-are moot if ISIS blows up some of our cities or if the borders are not fortified." Rank-and-file evangelicals "are trying to save the country" (Gabriel 2016). New York Times columnist Roger Cohen (2016) pointed to the same authoritarian dynamic, reinforced by Trump's unshakeable belief in himself:

Part of the Trump danger is that he's captured an American irredentism, a desire to reclaim something—-power, confidence, rising incomes - that many people feel is lost. Trump is a late harvest of $9 / 11$ and the fears that took hold that day. He's the focus of vague hopes and dim resentments that have turned him into a savior in waiting. . . . it's not the specifics with Trump, it's a feeling, a vibration-and no matter how much he dissembles, reveals himself as a thug, traffics in contradictions, the raptness persists. 
There is considerable evidence that humans with strong narcissistic motivations develop positive illusions about their own invincibility (McAdams 2015). As the evolutionary biologist Richard Wrangham (1999) has argued, positive illusions can promote overconfidence, which in turn may maximize individual fitness in many instances by motivating dominant behaviors like aggression and bluffing and by enhancing morale, resolve, and persistence (Johnson and Fowler 2011). Leaders with unrealistically high levels of confidence may be especially effective in recruiting allies and followers to fight for them, and to strive hard to accomplish difficult ends. Overconfidence in leaders, therefore, typically enhances the probability of victory in competitive situations by increasing coalition size. At the same time, overconfidence can, under certain conditions, lead to disastrous outcomes, Wrangham (1999) contends. History is filled with accounts of overconfident military leaders who, convinced that they would always prevail and that their cause was forever good, drove their fighters to ignominious defeat.

Complementing an aggressive, high-energy temperament and the positive illusions that follow from a narcissistic motivational agenda is Trump's internalized story of who he is and how he has come to be. Personality psychologists call such a story a person's narrative identity (McAdams 2013). Trump appears to be less introspective and psychologically minded than any president in modern history, so it is difficult to discern a coherent narrative identity. To the extent one exists, I would call it the myth of the warrior.

Found in many cultures worldwide, the archetypal hero of the warrior myth is courageous and brilliant. His response to any problem is to slay it or defeat it. His central life task is to fight for what matters. His greatest fear is weakness. Trump's narrative is about fighting to win, and it follows a plot that opens with punching his second-grade music teacher in the face (because Trump felt the teacher was not smart) and runs through the battles Trump fought as a business man and celebrity, nearly always winning, as he narrates it, to his fighting to win the biggest political contest on earth. As he wrote in The Art of the Deal, "Money was never a big motivation for me, except as a way to keep score" (Trump 1987, 63). Making money on business deals, or through reality TV, or branding-it merely reveals who the winner is. For Donald Trump, the story is always about fighting the battle, and emerging victorious, with the highest score. The hero of this story fights to win every day, no matter what the contest, no matter how big or trivial the opponent or the point. America must emulate this hero, the story says. America must learn how to win again.

\section{CONCLUSION}

Why did 63 million Americans elect a president of the United States who was repeatedly described during the campaign, by both Democrats and Republicans, as a serial liar, a sexual predator, a swindler, a narcissist, and a bully? There are many reasons. In this study, I have drawn upon our scientific understanding of human evolution and social/personality psychology to argue for a set of answers that have not heretofore received the attention they deserve. In so doing, I do not wish to dismiss or denigrate the many reasonable explanations that have been offered, and those that will surely be offered in the future, that derive from analyses of demographics, opinion polls, political strategies, economic forces, or the impact of singular world events and even chance happenings. Donald Trump's improbable_-and momentous - rise to political power cannot be fully explained by any single factor or theory.

The view advanced here is that Trump holds a deep and primal appeal for millions of Americans at this time in our history because of how effectively he channels the psychology of dominance-a way of thinking and feeling about leadership in groups that traces back 
many millions of years in human evolution, to our primate heritage. The dominance ethos competes with a more recently established sensibility regarding leadership in groups. The junior rival is the prestige psychology that began to take hold when our evolutionary ancestors crossed the Rubicon of cumulative cultural achievement, which itself launched the million-year run, still running, of culture-gene coevolution. From the standpoint of a prestige psychology, status derives from recognized cultural expertise; from the standpoint of a dominance psychology, it flows directly from brute force and intimidation.

It would seem that any chief executive of the United States, who is also the commander in chief of the nation's military, would invoke both prestige and dominance in the initial pursuit of the highest office in the land, and in governing thereafter. If President Obama tried to steer the ship of state slightly toward prestige psychology, Donald Trump has swerved violently in the opposite direction, creating a political and psychological whiplash. No U.S. president in recent memory, and perhaps none ever, has tapped so effectively into the primal psychology of dominance. None has so effectively cultivated an authoritarian dynamic with his followers, a direct and visceral relationship that plays out as much through Trump's Twitter account as it does through policy pronouncements and official executive actions.

Trump's appeal today derives from what Erik Erikson (1975) once characterized as the fateful coming together of a singular "life history" and a particular "historical moment." Trump's unique personality profile- the high extraversion and low agreeableness, the narcissistic motivations, the "warrior" life story—seems perfectly suited to assume the authoritarian mantel at a time in American history when many Americans crave the security and exult in the excitement that such a mantel seems to confer. Even as he creates chaos, Donald Trump-then as a candidate, and now as president of the United States-confidently assures Americans that he will deliver them from the chaos. We will be standing safe and strong in the end. We will win. We will dominate.

\section{WORKS CITED}

Adorno, Theodor W., Else Frenkel-Brunswik, Daniel J. Levinson, and R. Nevitt Sanford. 1950. The Authoritarian Personality. New York: Harper \& Brothers.

Allitt, Patrick. 2009. The Conservatives: Ideas and Personalities throughout American History. New Haven, CT: Yale University Press.

Altemeyer, Robert. 1996. The Authoritarian Specter. Cambridge, MA: Harvard University Press.

Baker, Peter, and Steven Erlanger. 2017. "Britain Furious as Trump Pushes Claim of Spying." New York Times, March 19.

Boehm, Christopher. 1999. Hierarchy in the Forest: The Evolution of Egalitarian Behavior. Cambridge, MA: Harvard University Press.

Bromwich, Jonah E. 2017. “Doomsday Clock Registers Cold-War-Type Pessimism." New York Times, January 27.

Cheng, Joey. T., Jessica L. Tracy, Tom Foulsham, Alan Kingstone, and Joseph Henrich. 2013. "Two Ways to the Top: Evidence That Dominance and Prestige Are Distinct Yet Viable Avenues to Social Rank and Influence." Journal of Personality and Social Psychology 104:103-25.

Chira, Susan. 2017. "'You Focus on the Good': Women Who Voted for Trump, in Their Own Words." New York Times, January 14.

Cohen, Roger. 2016. “Trump's II Duce Routine." New York Times, February 29.

D’Antonio, Michael. 2015. Never Enough: Donald Trump and the Pursuit of Success. New York: St. Martin's Press.

de Waal, Frans. 2007. Chimpanzee Politics: Power and Sex among Apes (25th Anniversary Edition). Baltimore: Johns Hopkins University Press. 
Duckitt, John, and Chris G. Sibley. 2010. "Personality, Ideology, Prejudice, and Politics: A Dual-process Motivational Model." Journal of Personality 78:1861-94.

Erikson, Erik H. 1975. Life History and the Historical Moment. New York: Norton.

Gabriel, Trip. 2016. “Donald Trump, Despite Impieties, Wins Hearts of Evangelical Voters." New York Times, February 27. Haidt, Jonathan. 2016. "When and Why Nationalism Beats Globalism." The American Interest 12 (1).

Haslam, Nick, and Michelle Stratemeyer. 2016. "Recent Research on Dehumanization." Current Opinion in Psychology 11:20-24.

Henrich, Joseph. 2016. The Secret of Our Success: How Culture Is Driving Human Evolution, Domesticating Our Species, and Making Us Smarter. Princeton, NJ: Princeton University Press.

Henrich, Joseph, and Francisco J. Gil-White. 2001. "The Evolution of Prestige: Freely Conferred Deference as a Mechanism of Enhancing the Benefits of Cultural Transmission." Evolution and Human Behavior 22:165-96.

Hetherington, Marc J., and Jonathan D. Weiler. 2011. Authoritarianism and Polarization in American Politics. New York: Cambridge University Press.

Johnson, Dominic P., and James H. Fowler. 2011. “The Evolution of Overconfidence." Nature 477:317-20.

Lausten, Lasse, and Michael B. Petersen. 2017. "Perceived Conflict and Leader Dominance: Individual and Contextual Factors behind Preferences for Dominant Leaders." Political Psychology. doi:10.1111/pops.12403.

MacWilliams, Matthew. 2016. "The One Weird Trait That Predicts Whether You're a Trump Supporter." Politico, January 17.

Maner, Jon K., and Charleen R. Case. 2016. "Dominance and Prestige: Dual Strategies for Navigating Social Hierarchies." In Advances in Experimental Social Psychology, edited by Mark P. Zanna and James M. Olson, 40:129-80. New York: Elsevier.

McAdams, Dan P. 2013. The Redemptive Self: Stories Americans Live By. New York: Oxford University Press. 2015. The Art and Science of Personality Development. New York: Guilford Press.

. 2016. "The Mind of Donald Trump." Atlantic, June, 76-90.

Molden, Daniel C., and Carol S. Dweck. 2006. "Finding 'Meaning' in Psychology: A Lay Theories Approach to SelfRegulation, Social Perception, and Social Development." American Psychologist 61:192-203.

Moyar, Mark. 2016. “The World Fears Donald Trump. That's a Good Thing." New York Times, December 9.

Rubenzer, Steven J., and Thomas R. Faschingbauer. 2004. Personality, Character, and Leadership in The White House: Psychologists Assess the Presidents. Dulles, VA: Brassey.

Shear, Michael D. 2016. "Trump as Cyberbully in Chief? Twitter Attack on Union Boss Draws Fire." New York Times, December 8.

. 2017. "Trump Arrives, Set to Assume Power." New York Times, January 20.

Sullivan, Andrew. 2006. The Conservative Soul: Fundamentalism, Freedom, and the Future of the Right. New York: Harper. Tracy, Jessica and Richard W. Robins. 2007. "Emerging Insights into the Nature and Function of Pride." Current Directions in Psychological Science 16: 147-150.

Trump, Donald J. 1987. The Art of the Deal. New York: Ballantine.

2015. Crippled America: How to Make America Great Again. New York: Simon \& Schuster.

Williams, Joan C. 2016. "What So Many People Don't Get about the U.S. Working Class." Harvard Business Review, November 10. https://hbr.org/2016/11/what-so-many-people-dont-get-about-the-u-s-working-class.

Wrangham, Richard. 1999. "Is Military Incompetence Adaptive?" Evolution and Human Behavior 20:3-17. 